\title{
EFFECTS OF TIMING OF LEAF REMOVAL ON YIELD, BERRY MATURITY, WINE COMPOSITION AND SENSORY PROPERTIES OF CV. GRENACHE GROWN UNDER NON IRRIGATED CONDITIONS
}

\author{
J. TARDAGUILA ${ }^{1} *$, Maria P. DIAGO ${ }^{1}$, F. MARTINEZ de TODA ${ }^{1}$, \\ S. PONI ${ }^{2}$ and $\mathrm{M}$. VILANOVA ${ }^{3}$ \\ 1: ICVV (Universidad de La Rioja, CSIC, Gobierno de La Rioja), \\ c/ Madre de Dios, 51, 26006 Logroño, Spain \\ 2: Istituto di Frutti-Viticoltura, Via Emilia Parmense 84, 29100 Piacenza, Italy \\ 3: Misión Biológica de Galicia (CSIC) PO Box 28, 36080 Pontevedra, Spain
}

\begin{abstract}
Aims: The objective of this study was to investigate the effects of timing of leaf removal on yield components, berry sensory characteristics, composition and sensory properties of Vitis vinifera L. Grenache wines under non-irrigated conditions.

Methods and results: The effects of timing of defoliation (fruit set and veraison) on yield components, berry maturity, wine composition and sensory properties of head trained, non irrigated, Grenache vines grown in Rioja appellation were studied. Leaf removal did not significantly modify total leaf area per vine as well as yield components. Grenache berries from early defoliated vines achieved the highest skin and technological maturity. Wine parameters, such as alcohol content, $\mathrm{pH}$, titratable acidity, tartaric acid and total polyphenol index were unaffected by defoliation. Conversely, early leaf removal carried out at fruit set, significantly reduced the malic acid content of the wine and enhanced its colour intensity. Aroma complexity, mouthfeel, tannin quality and persistence were found to be significantly higher in the wine corresponding to the early leaf removal treatment. This was also the most preferred wine in terms of overall value.
\end{abstract}

Conclusion: This article shows that timing of leaf removal had a marked effect on berry maturity, wine composition and sensory properties of Grenache wines made from grapes grown under dry-farmed conditions.

Significance and impact of study: The results suggest that the timing of defoliation induces significant changes in Grenache wine composition and its sensory attributes. Late leaf removal was much less effective than early leaf removal in affecting final wine composition and quality. Grenache wine from the early defoliation treatment was rated the most preferred as of global value.

Keywords: Grenache, Vitis vinifera L., defoliation, yield, berry sensory assessment, wine sensory properties, canopy management.

\section{Résumé}

Objectif: Le principal objectif de ce travail est de rechercher les effets de l'époque de l'effeuillage sur les principaux paramètres productifs, la composition chimique et les propriétés sensorielles des baies et des vins, du cépage Vitis vinifera L. cv Grenache, élevé sans irrigation.

Méthodes et résultats: On a étudié l'incidence du moment de l'effeuillage (nouaison et véraison) sur les rendements, la maturité du raisin et la composition et les propriétés sensorielles du cépage Grenache, sur des vignes non irriguées de l'appellation contrôlée Rioja. L'effeuillage n'a pas modifié significativement la surface foliaire totale et les rendements. Les baies du cépage Grenache provenant de vignes effeuillées précocement ont atteint une maturité phénolique et technologique optimale. Les principaux paramètres du vin, comme le degré alcoolique, le pH, l'acidité totale, la teneur en acide tartrique ainsi que l'indice de polyphénols totaux n'ont pas été affectés par l'effeuillage. Par contre, l'effeuillage précoce effectué à nouaison réduit significativement la teneur en acide malique dans le vin et augmente son intensité colorante. La complexité aromatique, le corps, la qualité des tanins et la persistance en bouche ont été significativement supérieurs pour le vin correspondant au traitement d'effeuillage précoce. Ce vin a été préféré pour l'ensemble des paramètres.

Conclusion : Cet article montre que l'époque de l'effeuillage a un effet très marqué sur la maturité de la baie, sur la composition du vin ainsi que sur les propriétés sensorielles des vins élaborés à partir des raisins provenant des vignes de Grenache cultivées sans irrigation.

\footnotetext{
Signification et impact de l'étude : Les résultats suggèrent que l'époque de l'effeuillage apporte des changements significatifs sur la composition et les propriétés sensorielles des vins de Grenache. L'effeuillage tardif a été beaucoup moins efficace que l'effeuillage précoce, en affectant la composition et la qualité finales du vin. Le vin élaboré à partir des raisins des vignes effeuillées précocement a été globalement préféré.
}

Mots clés : Grenache, Vitis vinifera L., effeuillage, récolte, évaluation sensorielle des raisins, propriétés sensorielles des vins, travail en vert 


\section{INTRODUCTION}

Grenache is the most widely planted red winegrape cultivar in the world and accounts for more than 300,000 ha (Dry, 2004). It is mainly grown around the north-western Mediterranean coast, particularly in Spain, France and Italy. In the early 1970s, Grenache was also the most important red variety in Australia (Dry, 2004). This variety has been described as showing excellent adaptation to hot and dry regions (Soar et al., 2006). In fact, Grenache, mainly head trained, is usually grown with no supplemental irrigation in Spain, Sardinia (Italy) and the south of France. Although Grenache cultivation has experienced, over the last decade, a decrease in favour of other cultivars such as Cabernet-Sauvignon, Shiraz or Tempranillo, some viticultural and enological experiences in Spain and Australia have suggested a re-evaluation of Grenache as a premium variety (Tardaguila and Martinez de Toda, unpublished).

Selective fruit zone leaf removal is a powerful technique to enhance cluster exposure to sunlight so as to improve grape and wine composition (Arnold and Bledsoe, 1990; Morrison and Noble 1990; Hunter et al., 1991; Staff et al., 1997). It has been well documented that cluster exposure influences the occurrence of disease and grape composition. Defoliation reduces both the incidence and severity of cluster rot (Gubler et al., 1992; Zoecklein et al., 1992; Percival et al., 1994). Sunlight-exposed clusters have shown higher levels of sugar content, anthocyanins, and phenolics and lower values of titratable acidity, malate content, $\mathrm{K}$ concentration and $\mathrm{pH}$ compared to shaded fruits (Crippen and Morrison, 1996; Smart et al., 1985; Morrison and Noble, 1990; Dokoozlian and Kliewer, 1996). These studies have concluded that increased exposure of fruit to sunlight improved both grape and wine composition. Generally speaking, grape colour depends on the degree of cluster exposure and the resulting berry temperature (Haselgrove et al., 2000; Bergqvist et al., 2001; Spayd et al., 2002). In the warm growing region of the Central San Joaquin Valley (California), Bergqvist et al., 2001 showed that anthocyanins and total phenolics in Grenache and Cabernet-Sauvignon increased linearly to increasing levels of sunlight exposure on the north side of the canopy, but declined with increasing levels of cluster exposure on the south side. From these findings, the authors suggested that the effects of light on fruit composition are heavily dependent on berry temperature.

While many studies have investigated the effects of leaf removal on grape and wine composition in several Vitis vinifera cultivars (Gubler et al., 1992; Zoecklein et al., 1992; Percival et al., 1994; Zoecklein et al., 1992; Staff et al., 1997; Smart et al., 1985; Petrie et al., 2000; Hunter et al., 1991; Bledsoe et al., 1988; Petrie et al.,
2003) scant information is still available on the relationship between cluster microclimate and vine balance modifications induced by leaf removal and the sensorial profile of the final wines.

Grape berry sensory analysis was first developed in France (Rousseau and Delteil, 2000) and has been proposed as a reliable tool to evaluate berries for ripeness, harvest scheduling and wine quality prediction (Winter et al., 2004). Wine descriptive analysis comprises a series of sensory techniques which intend to generate objective descriptions of wines in terms of the perceived aroma and taste attributes, and can be both qualitative and quantitative (Francis et al., 1992; Vilanova and Soto, 2005). Descriptive sensory analysis has been very rarely applied to study the effect of leaf removal on the aroma properties of wine (Arnold and Bledsoe, 1990).

The purpose of this study was to investigate how timing of leaf removal impinges on vine performance of non-irrigated Grenache and its degree of correlation to berry and wine sensory properties.

\section{MATERIAL AND METHODS}

\section{1- Vineyard site and experimental design}

The study was conducted in 2005 in a commercial Grenache (Vitis vinifera L.) vineyard located at Los Molinos de Ocon, in the wine-producing region of Rioja (Spain).Weather data (mean and maximum air temperature, rainfall) were recorded nearby the experimental site from April to October. The vines were planted in 1970 on a deep gravelly clay soil and grafted on 110R rootstock. All vines were head-trained and spur pruned. At winter pruning, 12 buds per vine were retained and all water shoots were pulled out in spring. Vine spacing was $3.0 \mathrm{~m}$ between rows and $1.1 \mathrm{~m}$ in the row. No irrigation or shoot trimming were applied. Other cultural practices were consistent with commercially accepted techniques. Treatments were arranged in a completely randomized design that consisted of five replicates of twenty-vine plots per treatment and defined as it follows: control (non defoliated vines), leaf removal at fruit-set (early defoliation) and veraison (late defoliation). Berries at fruit set and veraison were at stage 28 (3-4 mm diameter) and 35 (veraison), respectively, according to the grapevine growth stage classification proposed by Coombe 1995. Defoliation consisted in manually removing five primary basal leaves per shoot. All lateral shoots were retained.

\section{2- Yield components and leaf area}

At harvest, cane and cluster number as well as total yield were recorded on 10 vines per treatment. A 100berry sample was taken from each vine to estimate berry 
weight. Two shoots per vine were completely defoliated by manually removing and weighting all main and lateral leaves. Total leaf area per vine was then determined by comparing the fresh weight of 100 leaf discs of known area with the weight of 100 leaf samples per plot, using the method proposed by Smart and Robinson (1991).

\section{Vinification and wine analysis}

For each treatment, three replicates of approximately $80 \mathrm{~kg}$ of grapes each were harvested on 7 October 2005 at an average $250 \mathrm{~g} / \mathrm{L}$ of sugar content. Grapes were stored overnight in a cool chamber $\left(4^{\circ} \mathrm{C}\right)$ and the following day allowed to warm at room temperature before being destemmed and crushed. $\mathrm{SO}_{2}$ was added to the must at $50 \mathrm{mg} \mathrm{L}^{-1}$. Spontaneous fermentations were conducted in $100 \mathrm{~L}$ stainless steel tanks at $25^{\circ} \mathrm{C}$ for 14 days. All fermentations were run in triplicate and, once fermentation was complete, wines were separated from the skins. All samples were racked off and free $\mathrm{SO}_{2}$ content adjusted to $30 \mathrm{mg} \mathrm{L}^{-1}$ to prevent malolactic fermentation onset. After bottling, $1 \mathrm{~L}$ of each wine was stored at $10^{\circ} \mathrm{C}$ for further analysis. Alcohol content, titratable acidity, $\mathrm{pH}$, tartaric and malic acid were determined using a WineScan FT 120 multiple-parameter analyser (FOSS, Denmark). Colour intensity and total polyphenol index were determined by UV-VIS spectrophotometry. Colour intensity was calculated by adding absorbance values at 420, 520 and $620 \mathrm{~nm}$, whereas the total polyphenol index was determined by measuring the wine absorbance at $280 \mathrm{~nm}$ (EEC, 1990).

\section{Berry and wine sensory analysis}

Two days before harvest, a panel of seven trained and experienced winemakers evaluated berry sensory attributes using a modified method proposed by Winter et al. (2004). Flesh technological maturity (sweetness and acidity) and skin maturity (colour, herbaceous, acidic and astringent characteristics) of the berries were assessed in the vineyard using a scale ranging from 0 to 100 points.
Descriptive analysis of the wines was conducted by a panel of ten trained tasters three months after alcoholic fermentation completion and for five separate sessions. In the first session, the panellists became familiar with wine colour intensity and tonality using Munsell Book of Colour (1998) as well as with wine aroma sensory attributes by using standard references from the Nez du Vin (Lenoir, 1981). The panel was trained using different concentrations of quinine, tartaric acid, sodium chloride, glucose and glycerol in wine (table 1). The wine sensory descriptive analysis was performed in accordance with International Standard ISO 11035 (1994). To warrant maximum concentration to wine tasters in identifying descriptors, sensory analysis was performed in a professional room, in accordance with the ISO 8589 Standard (1988). A constant volume of $30 \mathrm{ml}$ of each wine was evaluated in wine-tasting glasses at $15^{\circ} \mathrm{C}$ as described in the ISO 3591 Standard (1977). The sensory analysis of the wines was performed in two sessions. Wine tasters evaluated nine wines in each session, each lasting $1 \mathrm{~h}$. The Grenache wines were evaluated to identify relevant attributes: colour (intensity and tonality), aroma (intensity, complexity, fruity, floral and grass), taste (mouthfeel, acidity, astringency, tannin quality and persistence) and global value. The intensity of each attribute was scored on a ten point scale, where: 0 indicated that the descriptor was not perceived and 9 that it was perceived at a very high intensity.

\section{Statistical analysis}

The data were subjected to analysis of variance (ANOVA). Mean comparisons were performed using Fisher's least significant difference (LSD) test; significance was set at $\mathrm{P}<0.05$. Principal component analysis (PCA) was performed to identify any factors differentiating the wines. All calculations were performed using the Enterprise Guide 3 System Software (SAS Institute, Cary, $\mathrm{NC}, \mathrm{USA})$.

Table 1 - Taste attributes concentrations used to train the panellists.

\begin{tabular}{cccccc}
\hline Taste & Compound & \multicolumn{4}{c}{ Concentrations } \\
\hline Sweet & Glucose & $5 \mathrm{~g} / \mathrm{L}$ & $10 \mathrm{~g} / \mathrm{L}$ & $15 \mathrm{~g} / \mathrm{L}$ & $20 \mathrm{~g} / \mathrm{l}$ \\
Acidity & Tartaric Acid & $0.2 \mathrm{~g} / \mathrm{L}$ & $0.5 \mathrm{~g} / \mathrm{L}$ & $1 \mathrm{~g} / \mathrm{L}$ & $1,5 \mathrm{~g} / 1$ \\
Salty & Sodium Chloride & $1 \mathrm{~g} / \mathrm{L}$ & $2 \mathrm{~g} / \mathrm{L}$ & $3 \mathrm{~g} / \mathrm{L}$ & $6 \mathrm{~g} / 1$ \\
Bitter & Quinine & $2.5 \mathrm{mg} / \mathrm{L}$ & $5 \mathrm{mg} / \mathrm{L}$ & $10 \mathrm{mg} / \mathrm{L}$ & $15 \mathrm{mg} / \mathrm{l}$ \\
Body & Glycerol & $5 \mathrm{~g} / \mathrm{L}$ & $10 \mathrm{~g} / \mathrm{L}$ & $15 \mathrm{~g} / \mathrm{L}$ & $20 \mathrm{~g} / \mathrm{L}$ \\
Astringency & Tannin & $0.2 \mathrm{~g} / \mathrm{L}$ & $0.5 \mathrm{~g} / \mathrm{L}$ & $1 \mathrm{~g} / \mathrm{L}$ & $1.5 \mathrm{~g} / \mathrm{L}$ \\
\hline
\end{tabular}




\section{RESULTS AND DISCUSSION}

The 2005 growing season (April to October) resulted to be quite dry as the mean temperature in July (hottest month) was $22.5^{\circ} \mathrm{C}$ and total rainfall for the growing season was $192 \mathrm{~mm}$, with only $8 \mathrm{~mm}$ of precipitations recorded in July-August (figure 1).

Timing of leaf removal did not significantly affect total leaf area per vine and yield components (table 2). Vines of both defoliated treatments showed more than $1.2 \mathrm{~m}^{2}$ of total leaf area per $\mathrm{kg}$ of grapes, thus implying a good balance according to the winegrape canopy ideotype proposed by Smart and Robinson (1991). The total leaf area per vine was moderate (less than $3.5 \mathrm{~m}^{2}$ per vine), so the canopy was not very dense. Clearly, both defoliation treatments compensated as total leaf area per vine likely due to enhanced shoot growth (main shoots were not trimmed) or to more vigorous lateral formation in the defoliated treatments. Similar results of leaf removal effects on yield components were found in other varieties (Kliewer and Bledsoe, 1987; Zoecklein et al., 1992). By contrast, Staff et al. (1997) have shown that leaf removal applied at bloom adversely affected crop yield and vine size, while other work showed that berry volume generally decreased with early defoliation (Staff et al., 1997; Ollat and Gaudillère, 1998; Poni et al., 2006). In our study, early leaf removal did not affect yield components, probably due to the low severity defoliation.

Sensory characteristics of Grenache berries were significantly affected by the timing of leaf removal. Early defoliation berries reached the highest technological maturity, whereas non defoliated grapes showed the lowest maturity ratings (figure 2). These results suggest that the timing of defoliation modified the flesh sweetness and acidity. Both leaf removal treatments induced a higher skin maturity in Grenache berries (figure 3). The comparison of data reported in figures 1 and 2 suggests that while timing of defoliation influenced flesh maturity, it did not modify any other sensory attributes of the skin berry such as herbaceousness or astringency.
Timing of leaf removal had no significant effect on the alcohol content, titratable acidity, $\mathrm{pH}$, tartaric acid and total polyphenols index in Grenache wines, whereas early leaf removal (fruit set) induced the lowest malic acid concentration and the highest colour intensity (table 3). Despite early defoliated vines had, on a vine basis, a total leaf area slightly higher than that recorded on the later leaf removal treatment, the response of lower malic acid can derive from more prolonged exposure of clusters to high light, hence, higher temperatures. Kliewer (1971) observed that leaf removal, improving fruit zone light penetration, advances berry maturation as a result of higher temperature and increased malate enzyme activity and the process of temperature-driven malic acid degradation is well known (Ruffner, 1982). More specifically, an environmentally controlled experiment from Buttrose $e t$ al. (1971) showed that lowering the temperature from $30^{\circ} \mathrm{C}$ to $20^{\circ} \mathrm{C}$ for 10 days either before or after the lagphase of berry growth had no effects of the concentration of malic acid in Cabernet-Sauvignon, whereas a temporary increase in temperature from $20^{\circ} \mathrm{C}$ to $30^{\circ} \mathrm{C}$ during the

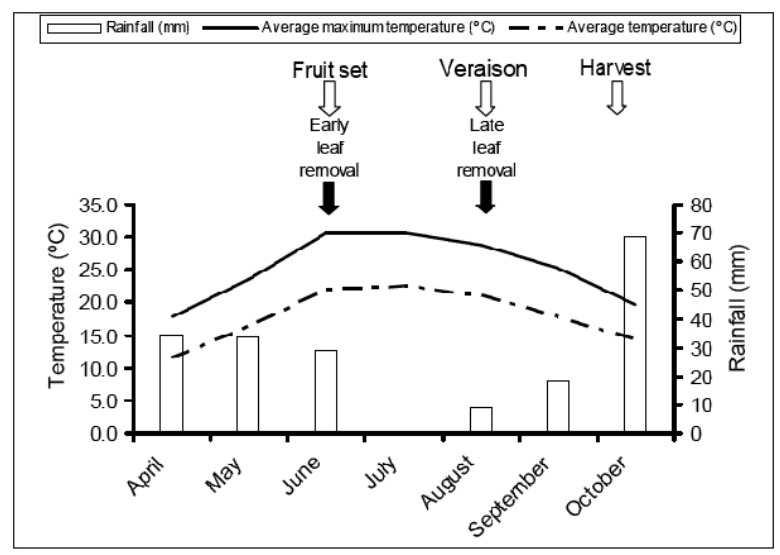

Figure 1 - Monthly average mean temperature, maximum temperature and rainfall at Agoncillo weather station (La Rioja, Spain) during the growing season (1 April-to 31 October) on 2005.

Table 2 - Influence of timing of leaf removal on yield components of Grenache grapevines.

\begin{tabular}{lcccc}
\hline \multicolumn{1}{c}{ Variable } & Control & Early leaf removal & Late leaf removal & Significance \\
\hline Total leaf area $\left(\mathrm{m}^{2} /\right.$ vine $)$ & 3.24 & 3.13 & 2.73 & NS \\
Berry weight $(\mathrm{g})$ & 1.89 & 1.85 & 1.86 & NS \\
Clusters per vine & 16.4 & 15.4 & 15.2 & NS \\
Cluster weight $(\mathrm{g})$ & 139 & 140 & 147 & NS \\
Yield (kg/vine) & 2.35 & 2.14 & 2.27 & NS \\
Total leaf area/yield $\left(\mathrm{m}^{2} / \mathrm{kg}\right)$ & 1.37 & 1.46 & 1.25 & NS \\
\hline
\end{tabular}

Statistical significance of treatments is given by $(*) \mathrm{p}=0.05$ and (NS) not significant. Mean values within columns were separated by LSD test $(\mathrm{p}=0.05)$. 


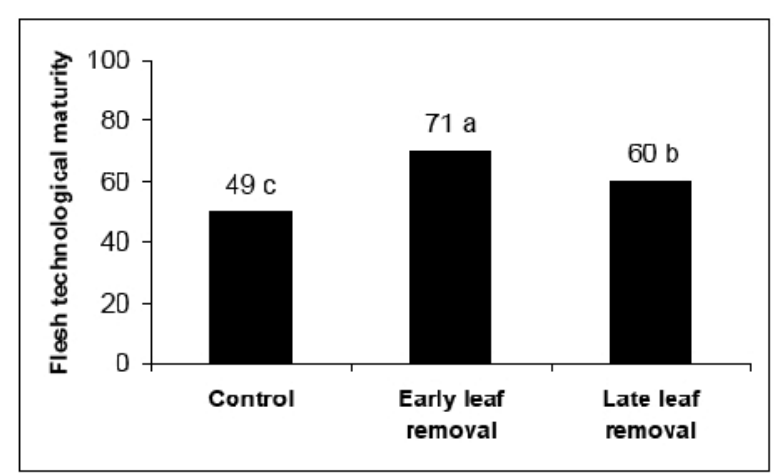

Figure 2 - Flesh technological maturity of Grenache berries

from different leaf removal treatments. 100 -point intensity scale was used.

Mean values were separated using Fishers LSD test $(\mathrm{P}=0.05)$.

Dissimilar letters across means indicate a statistically significant difference between those means.

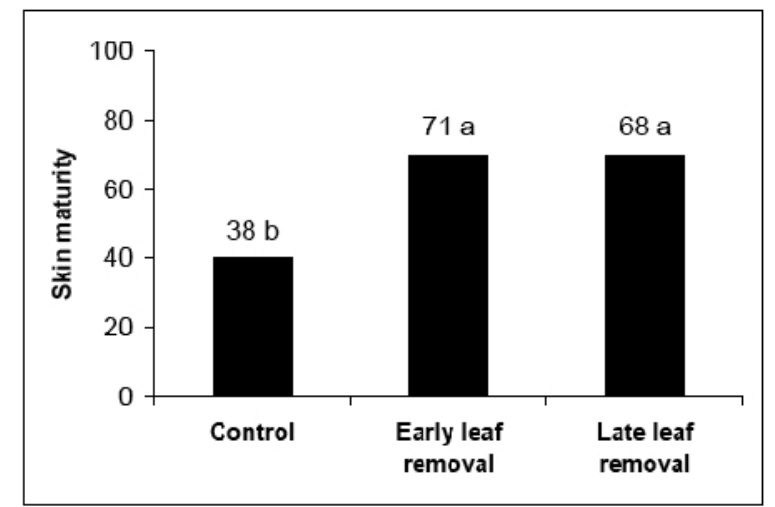

Figure 3 - Skin maturity of Grenache berries from different leaf removal treatments. 100 -point intensity scale was used.

Mean values were separated using Fishers LSD test $(\mathrm{P}=0.05)$. Dissimilar letters across means indicate a statistically significant difference between those means.

Table 3 - Effect of timing of leaf removal on composition of Grenache wines.

\begin{tabular}{lcccc}
\hline \multicolumn{1}{c}{ Variable } & Control & Early leaf removal & Late leaf removal & Significance \\
\hline Alcohol content (\%vol) & $14.6 \mathrm{a}$ & $14.8 \mathrm{a}$ & $14.7 \mathrm{a}$ & NS \\
$\mathrm{pH}$ & $3.20 \mathrm{a}$ & $3.14 \mathrm{a}$ & $3.20 \mathrm{a}$ & NS \\
Titratable acidity (g/L) & $7.2 \mathrm{a}$ & $7.4 \mathrm{a}$ & $7.4 \mathrm{a}$ & NS \\
Tartaric acid (g/L) & $0.89 \mathrm{a}$ & $1.04 \mathrm{a}$ & $0.88 \mathrm{a}$ & NS \\
Malic acid (g/L) & $1.93 \mathrm{a}$ & $1.58 \mathrm{~b}$ & $1.96 \mathrm{a}$ & $*$ \\
Colour intensity (AU) & $7.6 \mathrm{~b}$ & $8.5 \mathrm{a}$ & $7.6 \mathrm{~b}$ & $*$ \\
Total polyphenols index (AU) & $31.2 \mathrm{a}$ & $31.9 \mathrm{a}$ & $35.1 \mathrm{a}$ & NS \\
\hline
\end{tabular}

Statistical significance of treatments is given by $(*) p=0.05$ and (NS) not significant. Mean values within columns were separated by LSD test $(\mathrm{p}=0.05)$. Dissimilar letters across a row of treatment means indicate a statistically significant difference between those means.

same periods resulted in a consistent decrease in malic acid at the end of ripening. Poni et al. (2006) found that fruit-set defoliation performed in field-grown Trebbiano grapevines led to musts higher in soluble solids and tartaric acid, whereas $\mathrm{pH}$ values and malic acid concentrations were found to be lower, compared to those of untreated vine musts.

Tardaguila et al. (2005) have observed that Grenache berrie colour is dependent upon the leaf area/fruit yield ratio. In our study, leaf area/fruit yield ratio was unaffected, yet colour intensity was found to be higher for the wines corresponding to early leaf removal treatment. These results indicate that the effects induced by defoliation were more related to the local cluster microclimate rather than to the general source-sink balance of the vine. In a trial carried out on Grenache grown in the environment of the central San Joaquin Valley (Bergqvist et al., 2001), it was found that prolonged light exposure of clusters, leading in turn to overheating, should be avoided for maximum berry colour and a prevailing dappled light regime around the cluster should be preferred. In the present study, late leaf removal likely caused such instance as re-exposure of clusters to light was abrupt and permanent due to the probable mild reaction in lateral shoot development (table 2). Conversely, the earlier leaf removal might have triggered a progressive stronger lateral regrowth causing over time a partial shading of the ripening clusters that helped creating a sort of more favourable microclimate for pigmentation.

A summary of the analysis of variance (ANOVA) of Grenache wines for sensory attributes is given in table 4 . Sources of variation were wine, judge, replication and the wine $x$ judge interaction. The effect of the wine factor was found to be significant for all attributes, except for colour tonality, aroma intensity, grassiness, acidity and astringency. The effect of the judge factor was also found to be significant for all attributes and global value, except 


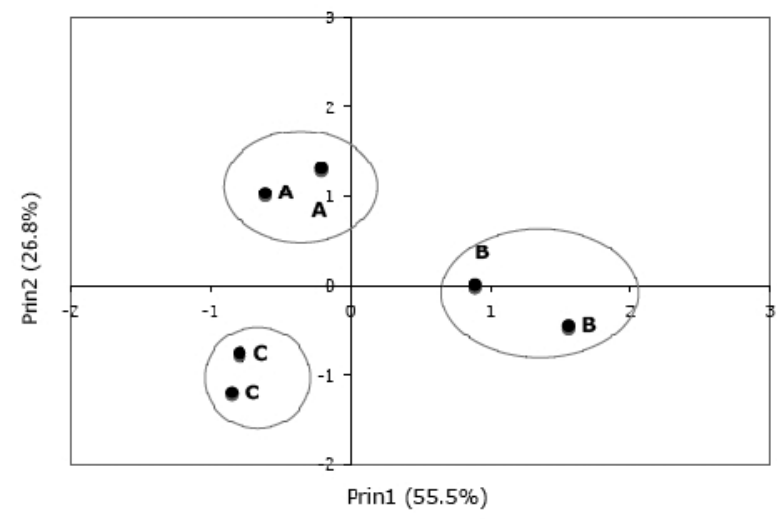

4a) Leaf removal treatments

( $\mathrm{A}=$ control, $\mathrm{B}=$ early leaf removal and $\mathrm{C}=$ late leaf removal)

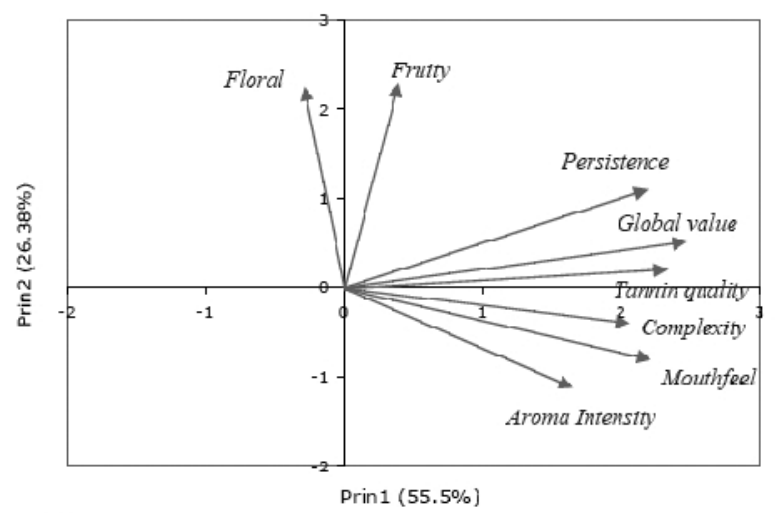

4b) Sensory attributes

Figure 4 - Principal components analysis (PCA) of sensory attributes of Grenache wines

for tannin quality. Conversely, the effect of the replication factor was found to be non-significant for all attributes, thus confirming that panellists were consistent in their wine assessment. The effect of wine $\mathrm{x}$ judge interactions revealed to be non-significant for most of the sensory descriptors, demonstrating that except for aroma complexity, fruity, floral, grass and taste persistence, the judges evaluated the wines in the same way. To this regard (wine $\mathrm{x}$ judge interaction), the significance $(\mathrm{P}<0.001)$ of three aroma attributes (complexity, floral and grassy) suggests that judges evaluated wine aroma with different perceptions. Tang et al. (1999) reported similar findings when samples were very similar in their sensory properties and the judges could not differentiate easily between them. Other authors considered that this is usual in descriptive analysis data of wine, because judges might use different parts of the scale (Tang et al., 1999; Poste et al., 1991; Douglas et al., 2001). As it regards global value, this study showed large differences in preference among the panellists, since the global value was found to be significantly different among wines $(\mathrm{p}<0.001)$ and judges $(\mathrm{p}<0.01)$.
Table 5 shows the mean intensity scores given by the panel of judges to 12 sensory attributes from different Grenache wines. Defoliation treatments led to significant differences in colour, aroma and taste among the Grenache wines. The timing of leaf removal caused significant changes in wine colour intensity, whereas wine hue or tonality remained unaffected. To this regard, the wines made from grapes that were defoliated at fruit set reached the highest scores in colour intensity. These results are consistent with the chemical composition of Grenache wines (table 3) and confirm that leaf removal at fruit set can improve colour intensity in Grenache wines, which are typically poorly coloured (Dry, 2004). Aroma attributes were significantly affected by the timing of defoliation (table 5). While aroma intensity and grassiness were similar among treatments, wines from early defoliated vines achieved the highest aroma complexity and both defoliation treatments displayed the lowest floral aroma. Highly significant differences existed among defoliation treatments for mouthfeel, tannin quality and persistence, although no significant differences were observed in terms of acidity and astringency. Mouthfeel, tannin quality and persistence reached their highest values in wines from early defoliated vines. Grenache wine from early defoliation was the most preferred in global value by the panellists. In other studies, leaf removal significantly improved wine colour (Hunter et al., 1991; Staff et al., 1997). Furthermore, Arnold and Bledsoe (1990) found that later leaf removal was less effective in reducing the intensity of vegetal aromas and flavour in the mouth in Sauvignon blanc wines.

Principal Component Analysis, including all 12 sensory attributes, was performed to graphically illustrate the correlations between scores given to the different descriptors (figure 4). The first two principal components accounted for $81.8 \%$ of total variance (55.5 and $26.3 \%$ ). The first principal component (Prin1) was characterized by aroma intensity, mouthfeel, complexity, tannin quality, global value and persistence having positive loadings. On the other hand, the second principal component (Prin2) was mostly explained by fruity and floral aroma, both attributes showing positive loadings. Descriptive analysis results have revealed distinctive sensory characteristics for different wines. It was clear that Grenache wines corresponding to different defoliation treatments were separated in terms of sensory attributes.

Finally, it could be assessed that leaf removal can be considered as a technique capable of modifying grape and wine quality in a costly effective manner. Moreover, in VSP vineyards, leaf removal is a technique easy to be mechanized with an estimated operation time of 1-1.5 hr/ha (Martinez de Toda and Tardaguila, 2003) and a cost of 60-80 per hectare (data not shown). 
Table 4 - Analysis of variance (ANOVA) of Grenache wines for sensory attributes and global value. $F$ ratios and significance for effects of wine, judge, repetition and wine $x$ judge interaction.

\begin{tabular}{|c|c|c|c|c|c|}
\hline \multirow{2}{*}{\multicolumn{2}{|c|}{$\begin{array}{c}\text { ANOVA } \\
\text { Sensory attribute }\end{array}$}} & \multicolumn{4}{|c|}{$F$ value } \\
\hline & & \multirow{2}{*}{$\frac{\text { Wine }}{29.07 * * *}$} & \multirow{2}{*}{$\begin{array}{c}\text { Judge } \\
8.97 * * *\end{array}$} & \multirow{2}{*}{$\begin{array}{c}\text { Repetition } \\
0.49^{\mathrm{NS}}\end{array}$} & \multirow{2}{*}{$\frac{\text { Wine x Judge }}{1.61^{\mathrm{NS}}}$} \\
\hline Colour & Intensity & & & & \\
\hline & Tonality & $2.56^{\mathrm{NS}}$ & $4.66 * *$ & $2.97^{\mathrm{NS}}$ & $0.63^{\mathrm{NS}}$ \\
\hline \multirow[t]{5}{*}{ Aroma } & Intensity & $1.93^{\mathrm{NS}}$ & $5.10 * * *$ & $0.49^{\mathrm{NS}}$ & $1.90^{\mathrm{NS}}$ \\
\hline & Complexity & $8.70 * *$ & $19.66 * * *$ & $1.21^{\mathrm{NS}}$ & $4.96 * * *$ \\
\hline & Fruity & $4.13 *$ & $8.99 * * *$ & $0.33^{\mathrm{NS}}$ & $2.67 *$ \\
\hline & Floral & $31.73 * * *$ & $14.44 * * *$ & $0.75^{\mathrm{NS}}$ & $5.73 * * *$ \\
\hline & Grass & $0.34^{\mathrm{NS}}$ & $30.03 * * *$ & $1.27^{\mathrm{NS}}$ & $6.16 * * *$ \\
\hline \multirow[t]{5}{*}{ Taste } & Mouthfeel & $23.56 * * *$ & $13.09 * * *$ & $1.51^{\mathrm{NS}}$ & $1.68^{\mathrm{NS}}$ \\
\hline & Acidity & $0.40^{\mathrm{NS}}$ & $2.35^{*}$ & $0.00^{\mathrm{NS}}$ & $0.72^{\mathrm{NS}}$ \\
\hline & Astringency & $1.76^{\mathrm{NS}}$ & $10.03 * * *$ & $3.21^{\mathrm{NS}}$ & $0.93^{\mathrm{NS}}$ \\
\hline & Tannin quality & $5.65 * *$ & $2.26^{\mathrm{NS}}$ & $0.00^{\mathrm{NS}}$ & $1.49^{\mathrm{NS}}$ \\
\hline & Persistence & $15.88 * * *$ & $6.32 * * *$ & $0.09^{\mathrm{NS}}$ & $2.07 *$ \\
\hline \multicolumn{2}{|c|}{ Global value } & $14.48 * * *$ & $4.55 * *$ & $1.27^{\mathrm{NS}}$ & $2.01^{\mathrm{NS}}$ \\
\hline \multicolumn{2}{|c|}{ Degrees of freedom } & 2 & 9 & 1 & 18 \\
\hline
\end{tabular}

Statistical significance of treatments is given by $(*) \mathrm{p}=0.05(* *) . \mathrm{p}=0.01(* * *) \mathrm{p}=0.001$ and (NS) not significant.

Table 5 - Mean \pm standard deviation for intensity of sensory attributes in Grenache wines.

\begin{tabular}{|c|c|c|c|c|c|}
\hline & y attribute & Control & $\begin{array}{c}\text { Early leaf } \\
\text { removal }\end{array}$ & $\begin{array}{c}\text { Late Leaf } \\
\text { removal }\end{array}$ & Sig. \\
\hline \multirow[t]{2}{*}{ Colour } & Intensity & $4.88 \pm 1.49 b$ & $6.77 \pm 0.87 \mathrm{a}$ & $5.33 \pm 1.18 b$ & $* * *$ \\
\hline & Tonality & $5.66 \pm 1.13 \mathrm{a}$ & $6.22 \pm 1.11 \mathrm{a}$ & $5.55 \pm 1.29 \mathrm{a}$ & NS \\
\hline \multirow[t]{5}{*}{ Aroma } & Intensity & $5.88 \pm 1.02 \mathrm{a}$ & $6.38 \pm 0.97 \mathrm{a}$ & $6.05 \pm 1.21 \mathrm{a}$ & NS \\
\hline & Complexity & $5.16 \pm 1.97 \mathrm{~b}$ & $6.00 \pm 1.32 a$ & $5.05 \pm 1.69 b$ & $* *$ \\
\hline & Fruity & $5.72 \pm 1.77 \mathrm{a}$ & $5.27 \pm 1.60 \mathrm{a}$ & $4.66 \pm 2.11 \mathrm{~b}$ & $*$ \\
\hline & Floral & $5.66 \pm 1.60 \mathrm{a}$ & $4.33 \pm 1.53 b$ & $3.61 \pm 1.88 \mathrm{~b}$ & $* * *$ \\
\hline & Grass & $3.55 \pm 2.38 \mathrm{a}$ & $3.77 \pm 2.04 \mathrm{a}$ & $3.61 \pm 2.35 \mathrm{a}$ & NS \\
\hline \multirow[t]{5}{*}{ Taste } & Mouthfeel & $4.72 \pm 1.52 b$ & $6.33 \pm 1.18 \mathrm{a}$ & $5.22 \pm 1.36 b$ & $* * *$ \\
\hline & Acidity & $5.55 \pm 1.38 \mathrm{a}$ & $5.33 \pm 0.84 a$ & $5.22 \pm 1.30 \mathrm{a}$ & NS \\
\hline & Astringency & $4.44 \pm 1.75 \mathrm{a}$ & $4.66 \pm 1.37 \mathrm{a}$ & $4.05 \pm 1.47 \mathrm{a}$ & NS \\
\hline & Tannin quality & $5.33 \pm 1.13 \mathrm{ab}$ & $6.00 \pm 1.23 \mathrm{a}$ & $4.77 \pm 1.39 b$ & $* *$ \\
\hline & Persistence & $5.50 \pm 1.50 \mathrm{a}$ & $6.27 \pm 1.07 \mathrm{a}$ & $4.55 \pm 1.42 b$ & $* * *$ \\
\hline \multicolumn{2}{|c|}{ Global value } & $5.44 \pm 1.33 b$ & $6.38 \pm 0.97 a$ & $4.88 \pm 1.13 b$ & $* * *$ \\
\hline
\end{tabular}

Statistical significance of treatments is given by $(*) p=0.05(* *) . p=0.01(* * *) p=0.001$ and (NS) not significant. Mean values within columns were separated by LSD test $(\mathrm{p}=0.05)$. Dissimilar letters across a row of treatment means indicate a statistically significant difference between those means. 


\section{CONCLUSIONS}

This study shows that timing of leaf removal had a marked effect on berry maturity, wine composition and sensory properties of Grenache wines made from grapes grown under dry-farmed conditions. The effects induced by defoliation were likely more related to the local cluster microclimate rather than to the general balance of the vine. Late leaf removal was much less effective than early leaf removal in modifying final wine composition and quality. The wine from the early defoliation treatment was rated the most preferred as of global value, by the panellists. Economically speaking, if it is considered that leaf removal is nowadays easily mechanizable and no adverse effects on yield were seen, defoliation carried out at fruit-set appears in the specific environment as a viable technique to increase the value of the grapes as well as appreciation of the final wine from the consumers.

\section{REFERENCES}

Arnold R.A. and Bledsoe A.M., 1990. The effect of various leaf removal treatments on the aroma and flavor of Sauvignon blanc wine. Am. J. Enol. Vitic., 41, 74-76.

Bergqvist J., Dokoozlian N. and Ebisuda N., 2001. Sunlight exposure and temperature effects on berry growth and composition of Cabernet-Sauvignon and Grenache in the Central San Joaquin Valley of California. Am. J. Enol. Vitic., 52, 1-7.

Buttrose M.S., Hale C.R. and Kliewer W.M. 1971. Effect of temperature on the composition of Cabernet-Sauvignon berries. Am. J. Enol. Vitic., 22, 71-75.

Coombe B.G., 1995. Adoption of a system for identifying grapevine growth stages. Aus. J. Grape Wine Res., 1, 104-110.

Crippen DD. and Morrison J., 1996. The effects of sun exposure on the phenolic content of Cabernet-Sauvignon berries during development. Am. J. Enol. Vitic., 37, 243-247.

Dokoozlian N.K. and Kliewer, W.M., 1996. Influence of light on the grape berry growth and composition varies during fruit development. J. Am. Soc. Hort. Sci., 121, 869-874.

Douglas D., Cliff M.A. and Reynols A.G., 2001. Canadian terroir: characterization of Riesling wines from the Niagara Peninsula. Food Res. Int., 34, 559-563.

Dry P.R., 2004. Grapevine varieties. In: Coombe B. and Dry P. (Eds.), Viticulture, Volume 1, Resources. Winetitles, Adelaide, pp. 132-149.

European Union Commission Regulation (EEC) No 2676/1990. Off. J. Europ. Comm. L 272.

Francis I.L., Sefton M.A. and Williams P.J., 1992. Sensory descriptive analysis of the aroma of hydrolyzed precursor fractions from Sémillon, Chardonnay and Sauvignon blanc grape juices. J. Sci. Food Agric., 59, 511-520.

Gubler W.D., Bettiga L.J. and Heil D., 1991. Comparisons of hand and machine leaf removal for the control of Botrytis cluster rot. Am. J. Enol. Vitic., 42, 233-236.
Haselgrove L., Botting D., van Heeswijck R., Hoj P.B., Dry P.R., Ford C. and Iland P.G., 2000. Canopy microclimate and berry composition: The effect of cluster exposure on the phenolic composition of Vitis vinifera L. cv. Shiraz grape berries. Aus. J. Grape Wine Res., 6, 136-140.

Hunter J.J., De Villiers O.T. and Watts J.E., 1991. The effect of partial on quality characteristics of Vitis vinifera L. cv. Cabernet-Sauvignon grapes. II. Skin color, skin sugar and wine quality. Am. J. Enol. Vitic., 42, 13-18.

ISO Standard 11035, 1994. Sensory analysis. Identification and selection of descriptors for establishing a sensory profile by a multidimensional approach.

ISO Standard 3591, 1977. Sensory analysis. Apparatus Wine Tasting Glass.

ISO Standard 8589, 1988. Sensory analysis. General guidance for the design of test rooms.

Kliewer W.M. and Bledsoe A., 1987. Influence of hedging and leaf removal on canopy microclimate, grape composition, and wine quality under California conditions. Acta Hort., 206, 157-168.

Kliewer W.M., 1971. Effect of day temperature and light intensity on concentration of malic and tartaric acids in Vitis vinifera $\mathrm{L}$. grapes. J. Am. Soc. Hort. Sci., 96, 372-377.

Lenoir J., 1981. Le Nez du Vin. Éditions Jean Lenoir, Carnoux in Provence.

Martínez de Toda and F. Tardaguila J., 2003. Meccanizzazione e fabbisogni di manodopera dei diversi sistemi di allevamento. In Forme di allevamento della vite e modalitá di distribuzione dei fitofarmaci. P. Balsari and A. Scienza (Eds.), pp. 143158. Bayer Cropscience, Milan, Italy.

Morrison J.C. and Noble A.C., 1990. The effects of leaf and cluster shading on the composition of Cabernet-Sauvignon grapes and on fruit and wine sensory properties. Am. J. Enol. Vitic. 41, 193-199.

Munsell A.E.O., 1998. Munsell Color: The Universal Language. Munsell Color, New York.

Ollat N. and Gaudillère J.P., 1998. The effect of limiting leaf area during stage I of berry growth on development and composition of berries of Vitis vinifera $\mathrm{L}$. cv. Cabernet Sauvignon. Am. J. Enol. Vitic., 49, 251-258.

Percival D.C., Fisher J.H. and Sullivan J.A., 1994. Use of fruit zone leaf removal with Vitis vinifera L. cv. Riesling grapevines. II. Effect on fruit composition, yield and occurrence of cluster rot (Botrytis cinerea pers.Fr). Am. J. Enol. Vitic., 45, 133-140.

Petrie P.R., Trought C.T. and Howell G.S., 2000. Influence of leaf ageing, leaf area and crop load and photosynthesis, stomatal conductance and senescence of grapevine (Vitis vinifera L. cv. Pinot noir) leaves. Vitis, 39, 31-36.

Petrie P.R., Trought C.T., Howell G.S. and Buchan G.D., 2003. The effect of leaf removal and canopy height on whole-vine gas exchange and fruit development of Vitis vinifera L. Sauvignon blanc. Functional Plant Biol., 30, 711-717.

Poni E., Casalini L., Bernizzoni F., Civardi S. and Intrieri C., 2006. Effects of early defoliation on shoot photosynthesis, yield components, and grape composition. Am. J. Enol. Vitic., 57, 397-407. 
Poste L.M., Mackie D.A., Butler and G. Larmond E., 1991. Laboratory methods for sensory analysis of food. Publication 1864/E. Research Branch, Agriculture Canada.

Rousseau J. and Delteil D., 2000. Présentation d'une méthode d'analyse sensorielle des raisins. Principe, méthode et grille d'interprétation. Rev. Fr. Enol., 183, 10-13.

Ruffner H.P. 1982. Metabolism of tartaric and malic acid in Vitis: A review - Part B. Vitis, 21, 346-358.

Smart R.E. and Robinson M., 1991. Sunlight into the wine: A handbook for winegrape canopy management. Winetitles, Adelaide.

Smart R.E., Robinson J.B., Due G.R. and Brien C.J., 1985. Canopy microclimate modification for the cultivar Shiraz II. Effects on must and wine composition. Vitis, 24, 119128.

Soar C.J., Speirs J., Maffe S.M., Penrose A.B., McCarthy M.G. and Loveys B.R., 2006. Grape vine varieties Shiraz and Grenache differ in their stomatal response to VPD: Apparent links with ABA physiology and gene expression in leaf tissue. Aus. J. Grape Wine Res., 12, 2-12.

Spayd S.E., Tarara J.M., Mee D.L. and Ferguson J.C., 2002. Separation of sunlight and temperature effects on the composition of Vitis vinifera cv. Merlot berries. Am. J. Enol. Vitic., 53, 171-182.
Staff S.L., Percival D.C., Sullivan, J.A., Fisher K.H., 1997. Fruit zone leaf removal influences vegetative, yield, disease, fruit composition and wine sensory attributes of Vitis vinifera $\mathrm{L}$. Optima and Cabernet franc. Can. J. Plant Sci., 7 7, 149153.

Tang C., Hsieh F., Heymann H. and Huff H., 1999. Analyzing and correlating instrumental and sensory data: a multivariate study of physical properties of cooked wheat noodles. J. Food Quality, 22, 193-211.

Tardaguila J., Njegovan M., Downey M. and Kristic, M., 2005. Determining the effect on cluster thinning of Sangiovese and Grenache composition. In Book of Abstracts of the International Workshop on Advances in Grapevine and Wine Research, Venosa, Italy, September 15-17, pp. 194.

Vilanova M. and Soto, B., 2005. The impact of geographic origin on sensory properties of Vitis vinifera cv. Mencía. J. Sensory Stud., 20, 503-511.

Winter E., Whiting J. and Rousseau J., 2004. Winegrape Berry Sensory Assessment in Australia. Winetitles, Adelaide.

Zoecklein B.W., Wolf T.J., Duncan N.W., Judge, J.M. and Cook M.K., 1992. Effects of fruit zone leaf removal on yield, fruit composition and fruit rot incidence of Chardonnay and white Riesling (Vitis vinifera L.) grapes. Am. J. Enol. Vitic., 43, 139-148. 